\title{
Searching for the Correlation Between the Activity of Urease and the Content of Nickel in the Soil Samples: The Role of Metal Speciation
}

\author{
Paweł Miśkowiec ${ }^{1}$ (D) Zofia Olech $^{1}$
}

Received: 14 January 2020 / Accepted: 5 May 2020 / Published online: 15 May 2020

(C) The Author(s) 2020

\begin{abstract}
The purpose of this study was to verify the correlation between the activity of urease and the content of nickel in soil of temperate climate in relation to the land management. Moreover, the metal speciation was taken into account in order to search for the above-mentioned correlation. Arable lands, forested lands, and wastelands were analyzed. The basic soil parameters were determined such as $\mathrm{pH}$, clay fraction content, and organic matter content. The speciation of nickel was studied by using BCR (Bureau Communitaire de Reference) sequential extraction procedure and flame atomic absorption spectrometry, while the urease activity was determined spectrophotometrically. The pseudo-total content of $\mathrm{Ni}$ in every sample was below $30 \mathrm{mg} \mathrm{kg}^{-1}$ of dry soil. The dominant form of nickel in the soil samples was the residual form. Although the urease activity varied slightly between the samples, the differences turned out to be statistically insignificant. However, the highly positive correlations between the urease activity, organic matter content, and the pseudo-total content of $\mathrm{Ni}$ were found and discussed. Moreover, the positive correlations between the urease activity and two geochemical forms of nickel, namely, active and residual form, were confirmed. The results of performed experiments prove that the method of land management does not significantly affect either the topsoil urease activity or the nickel distribution in the case of the extensive agriculture and forestry. However, the existence of at least two forms of the active soil urease was proposed. The first one-contained in the soil solution or loosely adsorbed on the soil particulates and the second one-strongly adsorbed onto the clay minerals. Also the complex role of the organic matter in protecting urease from external factors was presented. Finally, it was postulated that the nickel content in soil may be the indicator of the soil urease activity.
\end{abstract}

Keywords Soil urease $\cdot$ Nickel $\cdot$ BCR $\cdot$ Land management

\section{Introduction}

Urease, urea amidohydrolase with EC number 3.5.1.5, was the first enzyme ever to be extracted and crystallized, and its discovery was a landmark in enzymology. This compound is also known as the first protein to be identified as a nickelcontaining enzyme (Sumner 1926; Dixon et al. 1975; Boer et al. 2014).

Urease is found in a variety of plants, algae, fungi, invertebrates, and bacteria (Konieczna et al. 2013; El-Hefnawy

Paweł Miśkowiec

miskowie@chemia.uj.edu.pl

1 Department of Environmental Chemistry, Faculty of Chemistry, Jagiellonian University, Gronostajowa 2, 30-387, Krakow, Poland et al. 2014; Li et al. 2014). Despite the fact that urease molecules may differ in their structures, which is determined by the source of the enzyme, all of them hydrolyze urea in the same manner because the active unit in each urease enzyme is similar, namely, two nickel ions appear in the active site, and both of them are involved in the hydrolysis process. These nickel ions are bridged by a carboxylated lysine and a hydroxyl group. Nil is also coordinated by two histidine residues and a water molecule, while Ni2 is coordinated by two histidines, an aspartic acid residue and a water molecule (Carter et al. 2009; Carlsson and Nordlander 2010; Mathialagan et al. 2017).

Urease is also a soil enzyme, and its activity can be used as the indicator of the soil quality. Urease in the soil hydrolyzes the urea, and it acts as either an intracellular or extracellular enzyme. The intracellular activity is due to the presence of ureases in the living microorganisms. The extracellular 
activity refers to the enzyme molecules adsorbed on the soil organic and inorganic colloids or free enzymes in the soil solution. The extracellular enzymes are stated to be more stable than the intracellular ones; however, the mechanism of stabilization is still unclear. As mentioned above, the activity of the soil enzymes may be useful in the evaluation of the soil quality and in the verification of its contamination and degradation (Avellaneda-Torres et al. 2013; Zhang et al. 2016). The activity of the soil urease is important in terrestrial or even global nitrogen cycle, and it is well correlated with the level of nitrogen in the soil (Mocek-Płóciniak 2010; Qin et al. 2010; Freitas et al. 2018; Noor Affendi et al. 2020).

Nickel in natural soils occurs in trace concentration, but it turns out to be important for soil balance. Nickel deficiency causes disruption of basic physiological functions of plants growing in the soil, while excess of the metal is toxic to plants. Some authors studied the effect of Ni fertilization on restoring balance in soil (de Macedo et al. 2016; Freitas et al. 2019). Soil nickel supplementation has also been found to increase urease and dehydrogenase activity in the rhizosphere and to positively affect photosynthesis of soybean (Freitas et al. 2018). In the light of the foregoing facts, it is interesting to verify the correlation between the activity of urease being the nickel-dependent enzyme and the content of nickel adsorbed onto the soil particles. The investigations on the effect of metals on the soil enzyme activity usually concentrate on the total metal content which in case of $\mathrm{Ni}$ in soils varies widely (from 5 up to $500 \mathrm{mg} \mathrm{kg}^{-1}$ ), depending on soil $\mathrm{pH}$, soil contamination, and the type of plants grown (Rodak et al. 2015; Macedo et al. 2020). However, as it is well known, nickel, like most of heavy metals, occurs in different forms in soil (Vodyanitskii 2014). These geochemical forms determine metal solubility which is directly connected with its bioavailability.

In the environmental studies, the metal speciation provides the information about the nature and state of the trace metals as well as their bioavailability. Therefore the problem of the correlation between the urease activity and the nickel concentration in soil should be extended to involve also Ni speciation. Thus, the more precise question to ask should be whether it is possible to correlate the urease activity with the concentration of any of the nickel's form present in soil.

\section{Materials and Methods}

\subsection{Soil Sample Collection and their Preparation for Nickel Determination}

In our experiments, the podzol type of soil was analyzed. The samples were collected from arable lands (A), forested lands (F), and wastelands (W) to the depth of $0.3 \mathrm{~m}$ below the land surface (topsoil). None of the studied areas was subjected to intensive agrotechnical procedures. In every sampling area, one collected up to 15 subsamples from the square of approximately $20 \times 20 \mathrm{~m}$ size and mixed them up to give a bulk sample, weighing up to $1 \mathrm{~kg}$. The bulk soil samples, intended for nickel analysis, were air-dried, crushed, and sieved through a sieve with a mesh size of $2 \mathrm{~mm}$. Subsequently, every primary sample was divided into four equal parts. Three quarters of each sample were discarded, and the remaining quarter, marked as a laboratory sample, was used for the analysis.

In order to determine the pseudo-total content of nickel in soils, approximately $1.5 \mathrm{~g}$ of each sample, weighed to the nearest $0.0001 \mathrm{~g}$, was digested with the mixture of the concentrated nitric acid and $8.8 \mathrm{M}$ solution of hydrogen peroxide in a microwave oven. The high-performance digestion unit (MAGNUM II from Ertec, Wroclaw, Poland), with a compartment for a single PTFE digestion vessel designed for pressures up to 50 bar, served as the closed-pressurized microwave system.

Speciation analysis of nickel in soil was conducted using the modified Bureau Communitaire de Reference (BCR) method (Rauret et al. 2000). Four forms of nickel have been extracted. The first one was the exchangeable one, water and light acids soluble part of nickel (e.g., carbonates) (FM1); the second one was the form bound to iron and manganese oxides/hydroxides (FM2); the third one was the form bound to organic matter (FM3); and the fourth form, the residual part of metal, bound in clay lattice structure forms (FM4). For the extraction of particular metal forms, the following chemicals were used: to extract the FM1 form, the acetic acid was applied (at the concentration $0.11 \mathrm{M}$ ); for the FM2 form extraction, the hydroxylamine hydrochloride solution was used (at the concentration $0.5 \mathrm{M}$ ), whereas to extract the FM3 form, the mixture of 8.8 $\mathrm{M}$ hydrogen peroxide and ammonium acetate mixture was applied (at the concentration $1 \mathrm{M}, \mathrm{pH}=2$ ). In the procedure of extraction of nickel from the FM4 form, the mixture of concentrated $\mathrm{HNO}_{3}$ and $8.8 \mathrm{M}$ hydrogen peroxide was applied in the high-performance digestion unit instead of aqua regia, as originally described by Rauert. For each sample, two independent replicates were performed; in the same way, the blanks were measured for each set of analyses.

The solutions obtained from the digestion and from all the steps of BCR extraction were analyzed to determine the content of nickel with the flame atomic absorption spectrometry, using the Perkin Elmer apparatus AAnalyst 300. For each sample, three independent measurements were performed; the average value of nickel concentration and the relative standard deviation were calculated. In order to validate the method for the accuracy and precision, a certified reference material (CRM044-50G TRACE METALS-SILT LOAM 1) was analyzed in an analogous manner. The recovery was $93 \%$. The detection limit was determined as 3-fold standard deviation of repeated measurements of a blank solution and equaled for nickel $2.5 \mu \mathrm{g} \mathrm{dm}^{-3}$. 


\subsection{Soil Samples Preparation and Determination of the Urease Activity}

The surface samples $(0-30 \mathrm{~cm})$ of the soil, described earlier in this work, were crushed and sieved through a sieve with a mesh size of $2 \mathrm{~mm}$ right after drying in room temperature. Then, all the soil samples were put into polyethylene bags and stored at the temperature of $4-6{ }^{\circ} \mathrm{C}$ for 3 weeks.

The soil urease activity was determined spectrophotometrically by determination of the concentration of ammonia by using a modified Berthelot's method (Weatherburn 1967; Kandeler and Gerber 1988). The procedure was as follows: $10 \mathrm{~g}$ of soil, $13 \mathrm{~cm}^{3}$ of $200 \mathrm{mM}$ phosphate buffer $(\mathrm{pH}=7.0)$, $2.0 \mathrm{~cm}^{3}$ of $100 \mathrm{mM}$ EDTA solution, and $5.0 \mathrm{~cm}^{3}$ of $0.72 \mathrm{M}$ urea solution were put into Erlenmeyer flasks. The flasks were stoppered and incubated at $37^{\circ} \mathrm{C}$ for $24 \mathrm{~h}$. Then, $30 \mathrm{~cm}^{3}$ of $1 \mathrm{M} \mathrm{KCl}$ in $0.01 \mathrm{M} \mathrm{HCl}$ solution was added to each flask to stop the enzymatic reaction. All mixtures were shaken for $30 \mathrm{~min}$ and filtered afterward. A $1.0 \mathrm{~cm}^{3}$ of the filtrate was taken and placed in a $25.0 \mathrm{~cm}^{3}$ volumetric flask. Subsequently $4.0 \mathrm{~cm}^{3}$ of $0.1 \%$ sodium dichloroisocyanurate $(\mathrm{NaDCC})$ solution and $10.0 \mathrm{~cm}^{3}$ of the so-called reaction mixture (the composition of $0.12 \%$ sodium nitroprusside solution in $17 \%$ sodium salicylate solution, $0.3 \mathrm{M} \mathrm{NaOH}$ solution, and deionized water mixed 1:1:1 (volume ratio)) were added. The flask was made up to the mark. The absorbance of the solution was measured after $30 \mathrm{~min}$ at $690 \mathrm{~nm}$. All absorbance measurements were performed using the UV-Vis spectrophotometer Marcel Media ( $1 \mathrm{~cm}$ quartz cuvette) with deionized water in the reference cuvette.

The standard solution was prepared as follows: $3.8207 \mathrm{~g}$ $\mathrm{NH}_{4} \mathrm{Cl}$ was dissolved in water in the $1 \mathrm{dm}^{3}$ volumetric flask. The solution concentration was equal to $1000 \mu \mathrm{g} \mathrm{N}_{\mathrm{NH} 4+} \mathrm{cm}^{-3}$. The calibration curve was obtained for the diluted standard solutions: $0.25 ; 0.50 ; 0.75 ; 1.00 ; 1.25$; and $1.50 \mu \mathrm{g} \mathrm{N}_{\mathrm{NH} 4+}$ $\mathrm{cm}^{-3}$. Urease activity was expressed in $\mu \mathrm{g} \mathrm{N}_{\mathrm{NH} 4+}$ formed in $1 \mathrm{~g}$ of soil for $24 \mathrm{~h}, \mu \mathrm{g} \mathrm{N} \mathrm{NH}_{\mathrm{N}+} \mathrm{g}^{-1}(24 \mathrm{~h})^{-1}$.

\subsection{Determination of the Other Soil Physicochemical Properties}

The foregoing experiments were preceded by the determination of basic soil samples parameters, successfully applied in our previous studies (Miśkowiec et al. 2014, 2015):

- The $\mathrm{pH}$ was measured in $1.0 \mathrm{M}$ potassium chloride solution, pursuant to the ISO norm no. 10390:2005, using the Elmetron CP-401 pH meter device.

- The content of clay fraction was determined by Bouyoucos areometric method with Casagrande and Proszynski modification (Ryżak et al. 2009).
- The organic matter content was estimated using the $8.8 \mathrm{M}$ hydrogen peroxide pursuant to the regulation of the US Environmental Protection Agency (EPA) (Schumacher 2002).

\section{Results and Discussion}

The basic information on the soil parameters, as well as on the urease activity and the nickel concentration in the collected samples depending on the land management, are depicted in Tables 1 and 2. As shown in Table 1, all the investigated soils were slightly acidic, with the lowest values of $\mathrm{pH}$ for the forested lands. All the soil types were relatively poor in organic matter. However, this parameter was the highest for the forest soil. The amount of the clay fraction was low, about $2 \%$ in every sample. This information allows for the classification of all the soils as being "light." Soils of this type (acidic, poor in both organic matter and clay fraction) are in general susceptible for the external factors disrupting homeostasis including chemical contamination (Miśkowiec et al. 2015).

In Table 2, the results of the urease activity as $\mu \mathrm{g} \mathrm{N} \mathrm{NH}_{4+} \mathrm{g}^{-1}$ $(24 \mathrm{~h})^{-1}$ for the analyzed soils are presented. As it can be seen, the values collected for the analyzed soils do not differ drastically. Such results are typical for the soils of the temperate climate (Kang et al. 2009). However, some trends can be observed, namely, the average activity of urease for the forest lands is slightly higher than in the other soils. It can be concluded that the higher the level of the organic matter the stronger the activity of urease in the soil. This is regardless of $\mathrm{pH}$ value which is much below the optimum of urease activity reported to be 6.5-7.0 (Qin and Cabral 2002). The abovementioned observations are generally in accordance with the results obtained by other authors (Zhao et al. 2012; Sepken Kaptanoğlu Berber et al. 2014; Loeppmann et al. 2016). The high values of the standard deviation in comparison with both the mean and median of the results caused reasonable doubt as to the existence of any significant correlation between urease activity and the method of the land management. Thus, the potential correlation has been checked with the statistical Kruskal-Wallis test. The calculated test statistic $\mathrm{H}$ for urease activities of all three groups of land management equalled 0.97 , whereas the critical chi-square value for such a set of parameters and an alpha level of 0.05 is 5.991. Thus, the calculation presented allowed us to accept the null hypothesis that there are no statistical differences in urease activity between the questioned three groups of land management.

In the next step of our investigations, the nickel content in the soil samples was determined. The pseudo-total nickel content was calculated in two different manners, namely: 
Table 1 The basic parameters of the soils studied depending on the land management: $\mathrm{pH}$, organic matter content, and clay fraction content

\begin{tabular}{llllllllll}
\hline & \multicolumn{1}{l}{$\mathrm{pH}(\mathrm{KCl})$} & \multicolumn{4}{c}{ Organic matter content (\%) } & \multicolumn{3}{c}{ Clay fraction content (\%) } \\
\hline \multirow{3}{*}{ Mean } & $\mathrm{W}$ & $\mathrm{A}$ & $\mathrm{F}$ & $\mathrm{W}$ & $\mathrm{A}$ & $\mathrm{F}$ & $\mathrm{W}$ & $\mathrm{A}$ & $\mathrm{F}$ \\
Median & 4.85 & 4.55 & 3.77 & 1.99 & 2.52 & 3.65 & 2.2 & 2.1 & 2.1 \\
Minimum & 4.55 & 4.30 & 3.75 & 1.60 & 2.10 & 3.88 & 2.0 & 2.1 & 2.0 \\
Maximum & 3.70 & 3.80 & 3.30 & 1.38 & 1.46 & 1.09 & 1.5 & 1.7 & 1.6 \\
Standard deviation & 7.20 & 6.10 & 4.30 & 3.82 & 5.37 & 5.44 & 3.1 & 2.3 & 2.6 \\
& 1.27 & 0.85 & 0.36 & 0.93 & 1.46 & 1.58 & 0.7 & 0.2 & 0.4 \\
\hline
\end{tabular}

$W$ wastelands, $A$ arable lands, $F$ forested lands
- Directly from the nickel concentration in the solution obtained after mineralization of the soil sample with concentrated nitric acid and $8.8 \mathrm{M}$ hydrogen peroxide

- Indirectly, as the sum of the four forms of $\mathrm{Ni}$ obtained from the BCR sequential extraction

In all samples, the directly calculated pseudo-total nickel content varied between 92 and $103 \%$ of Ni content calculated indirectly. These differences can be considered as insignificant. Moreover, the results obtained from indirect calculations provide the information which can be reasonably related to the further results. Therefore, only the pseudo-total nickel content, calculated as the sum of particular nickel forms in the soil, is shown in Table 2.

The first visible conclusion is that the Ni content depends only slightly on the type of soil management. As was shown in the Fig. 1, the dominant form of nickel in the wastelands is the FM3 - bound to organic matter. In the remaining soil types, the FM4, the residual part of metal, presents the highest $\mathrm{Ni}$ concentration among the forms analyzed, followed by FM3 and FM2-bound to iron and manganese oxides/hydroxides. The concentration of $\mathrm{Ni}$ in soluble and exchangeable form (FM1) is the smallest in all cases. The results above described follow the typical order of total $\mathrm{Ni}$ concentration per form obtained among others by F.G. Macedo, et al., that is, bound to carbonate $<$ exchangeable $<$ bound to oxides $<$ organic matter $<$ residual (Macedo et al. 2020). Analyzing the results in
Table 2, it can be noticed that the total nickel content is the highest in the forested lands, whereas the lowest one is in the wastelands. In general, the increased nickel content in forested lands, especially in the FM4 form, is clearly noticeable. Furthermore, the concentration of $\mathrm{Ni}$ in wastelands $(\mathrm{W})$ is less varied than in the other samples (the lowest value of standard deviation). This may be caused by the lack of a strong anthropogenic impact resulting in a more stable soil condition, which also poses less threat for surface water contamination (Miśkowiec 2018). However, it is worth mentioning that Macedo et al. suggested that some "organic" Ni may be contained in microorganisms living in organic matter fraction, which may interfere with the correct assessment of its content (Macedo et al. 2020). To sum up, the variation of the content of this metal in soil is mainly due to the nickel in the residual form. This can be found for all types of the studied soil. In most cases, such a predominant form of nickel bonding is in general typical for this metal in non-contaminated and poorly fertilized soils (Kuziemska et al. 2014). The sum of the total non-residual Ni form (FM1-FM3) concentration ranges between 3.6 and $7.4 \mathrm{mg} \mathrm{kg}^{-1}$ of soil which is on the background level. Considering the results related to these three forms, the correlations between the level of nickel and the method of the soil management are rather poorly observable, which was confirmed with the statistical Kruskal-Wallis test. It is also important to notice that, even while taking the pseudo-total nickel content into account, none of the samples exceeded the

Table 2 Urease activity and nickel content in the studied soils, depending on the land management

\begin{tabular}{|c|c|c|c|c|c|c|c|c|c|c|c|c|c|c|c|c|c|c|}
\hline & \multirow{2}{*}{\multicolumn{3}{|c|}{$\begin{array}{l}\text { Urease activity }\left(\mu \mathrm{g} \mathrm{N} \mathrm{g}^{-1}\right. \\
\left.\text { soil }(24 \mathrm{~h})^{-1}\right)\end{array}$}} & \multirow{2}{*}{\multicolumn{3}{|c|}{$\begin{array}{l}\text { Pseudo-total content of } \\
\mathrm{Ni}\left(\mathrm{mg} \mathrm{kg}^{-1}\right)\end{array}$}} & \multicolumn{12}{|c|}{ Content of different forms of $\mathrm{Ni}\left(\mathrm{mg} \mathrm{kg}^{-1}\right)$} \\
\hline & & & & & & & \multicolumn{3}{|c|}{ FM1 } & \multicolumn{3}{|l|}{ FM2 } & \multicolumn{3}{|c|}{ FM3 } & \multicolumn{3}{|l|}{ FM4 } \\
\hline & $\mathrm{W}$ & $\mathrm{A}$ & $\mathrm{F}$ & $\mathrm{W}$ & A & $\mathrm{F}$ & W & $\mathrm{A}$ & $\mathrm{F}$ & $\mathrm{W}$ & A & $\mathrm{F}$ & $\mathrm{W}$ & A & $\mathrm{F}$ & W & A & $\mathrm{F}$ \\
\hline Mean & 319.3 & 365.2 & 416.4 & 8.09 & 11.07 & 14.16 & 1.01 & 0.93 & 0.96 & 1.51 & 1.82 & 1.56 & 3.73 & 2.52 & 3.00 & 1.85 & 5.80 & 8.64 \\
\hline Median & 281.5 & 299.9 & 427.0 & 7.88 & 7.78 & 15.46 & 1.11 & 0.95 & 0.99 & 1.52 & 1.72 & 1.63 & 4.27 & 2.10 & 3.30 & 1.69 & 2.56 & 10.23 \\
\hline Minimum & 173.8 & 197.4 & 207.2 & 6.65 & 5.38 & 6.46 & 0.05 & 0.06 & 0.52 & 0.87 & 1.34 & 0.79 & 1.79 & 1.49 & 1.48 & 0.05 & 0.07 & 0.87 \\
\hline Maximum & 604.0 & 828.5 & 662.9 & 9.91 & 25.93 & 20.70 & 1.53 & 1.75 & 1.30 & 2.11 & 2.57 & 2.41 & 5.04 & 3.90 & 4.16 & 5.12 & 19.85 & 14.61 \\
\hline Standard deviation & 91.0 & 168.6 & 154.7 & 1.22 & 7.80 & 5.78 & 0.52 & 0.55 & 0.30 & 0.50 & 0.46 & 0.63 & 1.41 & 1.06 & 1.25 & 1.82 & 7.76 & 6.05 \\
\hline
\end{tabular}

$W$ wastelands, $A$ arable lands, $F$ forested lands. $F M 1-F M 4$, four different forms of metal binding in soils, explained in detail in the text 
Fig. 1 The mean relative content of nickel in the soils studied, with the division in four metal forms gained with the BCR extraction method. FM1, water and light acids soluble part of nickel; FM2, the form bound to iron and manganese oxides/hydroxides; FM3, the form bound to organic matter; FM4, the residual part of metal, bound in clay lattice structure forms

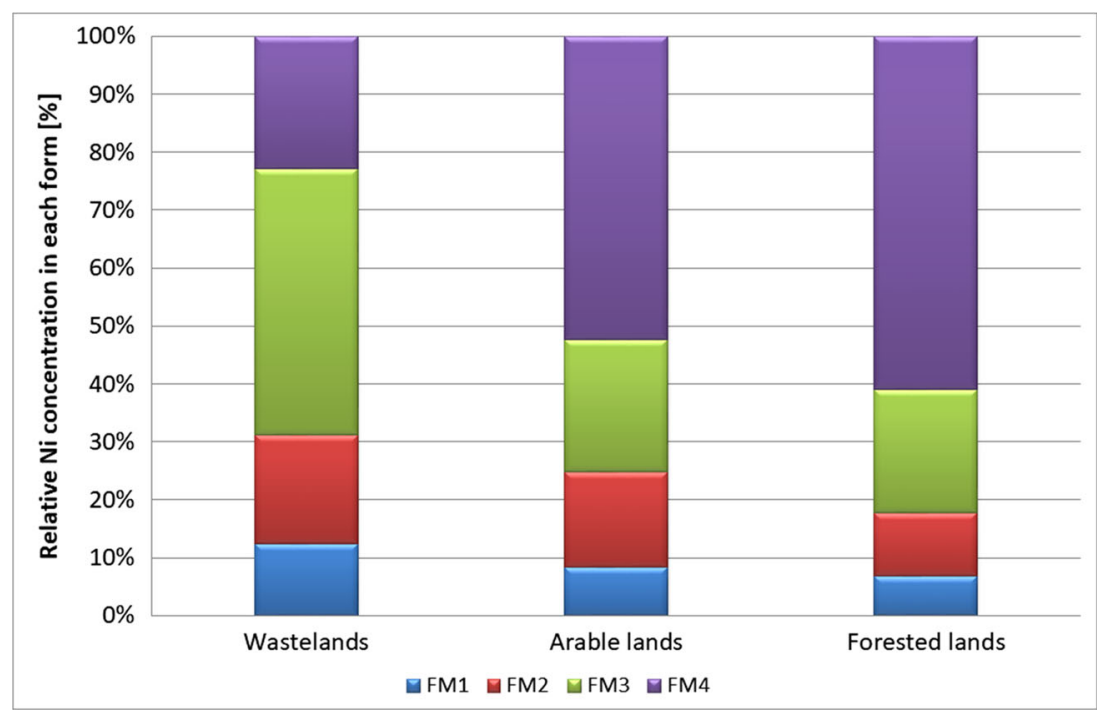

limit of $30 \mathrm{mg} \mathrm{kg}^{-1}$ of dry mass. The latter value is considered the upper limit of non-contaminated land (Kabata-Pendias et al. 1995) (however, according to other studies, the value $50 \mathrm{mg} \mathrm{kg}^{-1}$ is the threshold concentration in European soils (Tóth et al. 2016)) . In 80\% of samples, the content of nickel was lower than $10 \mathrm{mg} \mathrm{kg}^{-1}$ of dry mass of soil, which is coherent with the results reported in literature (KabataPendias 2010). Summarizing, one can state that the differences in the nickel content in particular soil types originated mainly from the concentration of nickel in the residual form.

Figure 2 presents the 3-D chart of the soil urease activity, the nickel content, and the amount of organic matter dependencies.
The comparison of those three parameters gives relatively high positive correlations, namely, the urease activity was found to increase with the level of organic matter and with the content of nickel in the sample. The calculated Pearson correlation coefficients turned out to be above 0.70 in all three cases (urease activity, nickel content 0.86 ; urease activity, organic matter content 0.75 ; nickel content, organic matter content 0.83 ).

The similar calculations were made in relation to the four forms of nickel to get knowledge whether any of the metal forms is particularly correlated with the urease activity. The obtained results of the correlation between the concentration of nickel in particular forms (FM1-FM4) and the urease
Fig. 2 3-D chart depicting the dependences between urease activity, organic matter content, and nickel content in the soils studied (red balls). Circles, triangles, and squares are the projections of the chart on individual 2D planes, showing the relationships between particular two parameters. The Pearson correlation coefficients are as follows: urease activity-nickel content (circles) 0.86; urease activity-organic matter content (triangles) 0.75 ; and nickel content-organic matter content (squares) 0.83

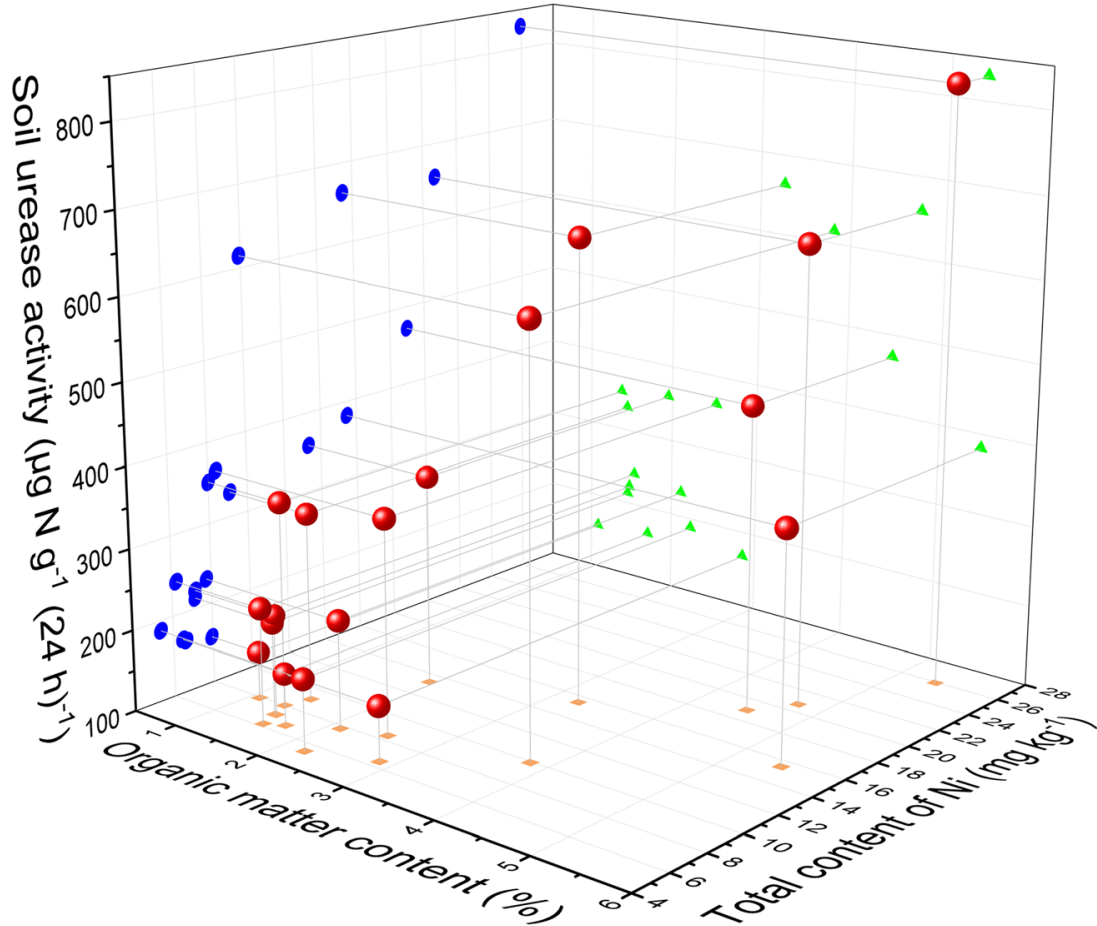


activity differed fundamentally depending on the nickel form. Correlation coefficients between urease activity and the FM2 and the FM3 forms equalled 0.01 and -0.35 respectively. On the other hand, a significant correlation (Pearson coefficient higher than 0.50 ) was found between the urease activity and the exchangeable $(0.57)$ or residual $(0.86)$ form of $\mathrm{Ni}$. The latter two correlations were graphically presented in Fig. 3a and $\mathrm{b}$. Two seemingly contradictory facts are worth highlighting. The first is the lack of a strong correlation between the urease activity and the content of nickel bound to organic matter (FM3). At the same time, there is a strong correlation between the urease activity and organic matter content as well as the pseudo-total nickel concentration (Fig. 2). These facts clearly reveal the role of organic components in this system-less as the absorbing medium and more as the "protectors" of the labile enzyme. Such a complex role of organic matter as the stabilizer of urease by the association of this enzyme with the soil colloids was suggested by a few authors (Nannipieri et al. 1996). The other emphasized both the complex role of the microorganisms in this system (Macedo et al. 2020) and their potential role in bioprecipitation (Jalilvand et al. 2020). However, our studies let us draw even further and stronger conclusions about the key role of organic components in extracellular urease protection.
Fig. 3 Correlations between content of the two forms of nickel and urease activity. a FM1, water and light acids soluble form of nickel. b FM4, the residual part of metal, bound in clay lattice structure forms. The Pearson correlation coefficients equal 0.57 and 0.86 , respectively
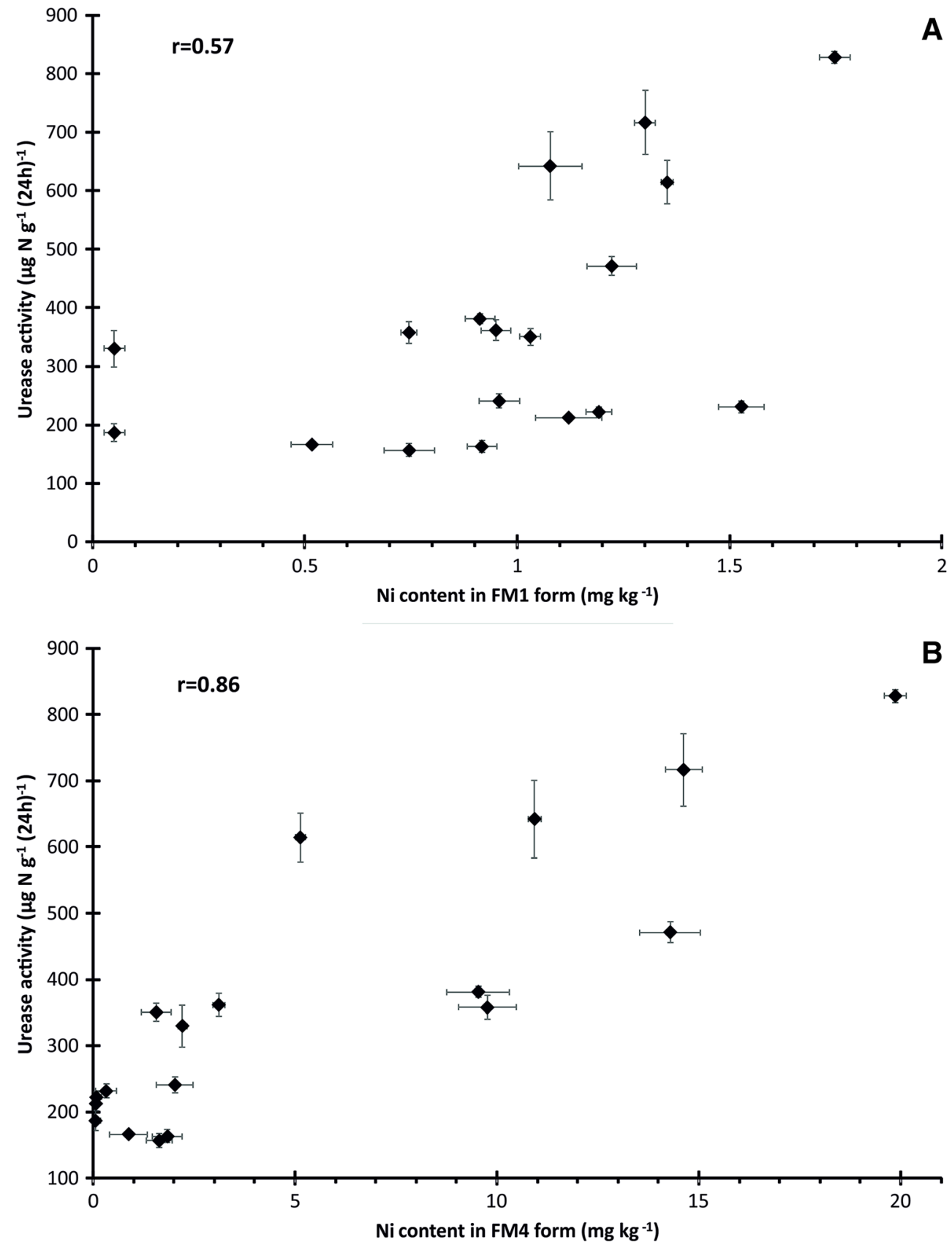
The fact that the urease activity was highly correlated with the concentration of nickel in its most available form (Fig. 3a), is not surprising and can be expected if based on the results of the data in literature (Marschner 1995; Vahed et al. 2011; Oliveira et al. 2013; Zhang et al. 2014). However, the second strongly positive correlation found in our experiments, between the urease activity and the nickel content in the socalled residual form (Fig. 3b), was unexpected. This is because the metals in this form are tightly bound to the mineral structures in the soil and cannot be released under natural conditions; thus, they are considered as biologically unavailable (Ideriah et al. 2013). This fact may be a confirmation of the strong and stable linkage of this enzyme with clay minerals resistant to the external factors.

\section{Conclusions}

In this study, we postulate the existence of at least two forms of soil urease in terms of the affinity of this enzyme to the clay minerals. On one hand, urease is dissolved in the soil solution or loosely connected with the solid components, like mineral colloidal particles. On the other hand, our studies seems to confirm that some part of the soil urease may be strongly adsorbed on the clay minerals in a stable and functioning form. Moreover, the organic matter stabilizes this system and acts against the decay of this labile enzyme. The question on how exactly the organic matter protects urease from the destruction should be the subject for future studies. These issues have become even more important in the light of the recent research, concerning new methods of removing heavy metals from soil using bioprecipitation by ureolytic soil bacteria. Moreover, owing to existence of such correlations, the nickel content in unpolluted lands may thus be kind of an indicator of the urease activity and indirectly of the quality of the soil, regardless of the method of land management.

Acknowledgments We would like to express our gratitude to M.A. Marta Mikołajczyk who assisted us in experiments and therefore contributed to the success of our research.

\section{Compliance with Ethical Standards}

Conflict of Interest The authors declare that they have no conflict of interest.

Open Access This article is licensed under a Creative Commons Attribution 4.0 International License, which permits use, sharing, adaptation, distribution and reproduction in any medium or format, as long as you give appropriate credit to the original author(s) and the source, provide a link to the Creative Commons licence, and indicate if changes were made. The images or other third party material in this article are included in the article's Creative Commons licence, unless indicated otherwise in a credit line to the material. If material is not included in the article's Creative Commons licence and your intended use is not permitted by statutory regulation or exceeds the permitted use, you will need to obtain permission directly from the copyright holder. To view a copy of this licence, visit http://creativecommons.org/licenses/by/4.0/.

\section{References}

Avellaneda-Torres LM, Melgarejo LM, Narváez-Cuenca CE, Sánchez J (2013) Enzymatic activities of potato crop soils subjected to conventional management and grassland soils. J Soil Sci Plant Nutr 13: 301-312. https://doi.org/10.4067/S0718-95162013005000025

Boer JL, Mulrooney SB, Hausinger RP (2014) Nickel-dependent metalloenzymes. Arch Biochem Biophys 544:142-152. https://doi. org/10.1016/j.abb.2013.09.002

Carlsson H, Nordlander E (2010) Computational modeling of the mechanism of urease. Bioinorg Chem Appl. https://doi.org/10.1155/ 2010/364891

Carter EL, Flugga N, Boer JL et al (2009) Interplay of metal ions and urease. Metallomics 1:207-221. https://doi.org/10.1039/b903311d

de Macedo FG, Bresolin JD, Santos EF et al (2016) Nickel availability in soil as influenced by liming and its role in soybean nitrogen metabolism. Front Plant Sci. https://doi.org/10.3389/fpls.2016.01358

Dixon NE, Gazzola C, Blakeley RL, Zerner B (1975) Jack Bean Urease (EC 3.5.1.5). A Metalloenzyme. A Simple Biological Role for Nickel? J Am Chem Soc 97:4131-4133. https://doi.org/10.1021/ ja00847a045

El-Hefnawy ME, Sakran M, Ismail AI, Aboelfetoh EF (2014) Extraction, purification, kinetic and thermodynamic properties of urease from germinating Pisum sativum L. seeds. BMC Biochem. https://doi. org/10.1186/1471-2091-15-15

Freitas DS, Rodak BW, Carneiro MAC, Guilherme LRG (2019) How does Ni fertilization affect a responsive soybean genotype? A dose study. Plant Soil 441:567-586. https://doi.org/10.1007/s11104-01904146-2

Freitas DS, Wurr Rodak B, Rodrigues dos Reis A et al (2018) Hidden nickel deficiency? Nickel fertilization via soil improves nitrogen metabolism and grain yield in soybean genotypes. Front Plant Sci. https://doi.org/10.3389/fpls.2018.00614

Ideriah TJK, Ikpe FN, Nwanjoku FN (2013) Distribution and speciation of heavy metals in crude oil contaminated soils from Niger Delta, Nigeria. World Environ 2013:18-28. https://doi.org/10.5923/j.env. 20130301.03

Jalilvand N, Akhgar A, Alikhani HA et al (2020) Removal of heavy metals zinc, lead, and cadmium by biomineralization of ureaseproducing bacteria isolated from Iranian mine calcareous soils. $\mathrm{J}$ Soil Sci Plant Nutr 20:206-219. https://doi.org/10.1007/s42729019-00121-z

Kabata-Pendias A (2010) Elements of Group 10 (Previously Part of Group VIII). In: Trace Elements in Soils and Plants. CRC Press, Fourth Edition, pp 237-251

Kabata-Pendias A, Piotrowska M, Motowicka-Terelak T, et al. (1995) The fundamentals of assessment of chemical contamination of soils. Heavy metals, sulfur and PAHs. IUNG, Warszawa.

Kandeler E, Gerber H (1988) Short-term assay of soil urease activity using colorimetric determination of ammonium. Biol Fertil Soils 6:68-72. https://doi.org/10.1007/BF00257924

Kang H, Kang S, Lee D (2009) Variations of soil enzyme activities in a temperate forest soil. Ecol Res 24:1137-1143. https://doi.org/10. 1007/s11284-009-0594-5

Konieczna I, Zarnowiec P, Kwinkowski M et al (2013) Bacterial urease and its role in long-lasting human diseases. Curr Protein Pept Sci 13: 789-806. https://doi.org/10.2174/138920312804871094

Kuziemska B, Kalembasa S, Wieremiej W (2014) Distribution of nickel in fractions extracted with the BCR procedure from nickel - 
contaminated soil. J Elemntology 697-708. https://doi.org/10.5601/ jelem.2014.19.3.702

Li Q, Csetenyi L, Gadd GM (2014) Biomineralization of metal carbonates by Neurospora crassa. Environ Sci Technol 48:14409-14,416. https://doi.org/10.1021/es5042546

Loeppmann S, Semenov M, Blagodatskaya E, Kuzyakov Y (2016) Substrate quality affects microbial- and enzyme activities in rooted soil. J Plant Nutr Soil Sci 179:39-47. https://doi.org/10.1002/jpln. 201400518

Macedo FG, Santos EF, Lavres J (2020) Agricultural crop influences availability of nickel in the rhizosphere; a study on base cation saturations, Ni dosages and crop succession. Rhizosphere. https:// doi.org/10.1016/j.rhisph.2019.100182

Marschner H (1995) 9 - Functions of mineral nutrients: micronutrients. In: Second E (ed) Marschner HBT-MN of HP. Academic Press, London, pp 313-404

Mathialagan R, Mansor N, Al-Khateeb B et al (2017) Evaluation of allicin as soil urease inhibitor. Procedia Eng 184:449-459. https:// doi.org/10.1016/j.proeng.2017.04.116

Miśkowiec P (2018) Contamination of small watercourses with heavy metals depending on distance from emission sources: Lesser Poland case study. Water Environ J 32:197-208. https://doi.org/10. 1111/wej.12315

Miśkowiec P, Łaptas A, Ślusarska M (2014) Metale ciężkie w glebach Doliny Prądnika (Heavy metals in the soils of the Prądnik Valley). Pradnik Pr i Mater Muz im Prof Wł Szafera 24:131-138

Miśkowiec P, Łaptaś A, Zięba K (2015) Soil pollution with heavy metals in industrial and agricultural areas: a case study of Olkusz District. J Elem 2:353-362. https://doi.org/10.5601/jelem.2014.19.3.691

Mocek-Płóciniak A (2010) Utilisation of enzymatic activity for the evaluation of the impact of anthropogenic changes caused by heavy metals in soil environment. Nauk Przyr Technol 4:\#86. https://doi. org/10.17306/J.NPT.2010.6.86

Nannipieri P, Sequi P, Fusi P (1996) Humus and enzyme activity. In: Piccolo A (ed) Humic Substances in Terrestrial Ecosystems. Elsevier Science B.V., pp. 293-328.

Noor Affendi NM, Mansor N, Samiri SS (2020) Addition of chemical and natural urease inhibitors in reducing ammonia and nitrous oxide losses. J Soil Sci Plant Nutr 20:253-258. https://doi.org/10.1007/ s42729-019-00136-6

Oliveira TC, Fontes RLF, de Rezende ST, Víctor Hugo Alvarez V (2013) Effects of nickel and nitrogen soil fertilization on lettuce growth and urease activity. Rev Bras Cienc do Solo 37:698-706. https://doi.org/ 10.1590/S0100-06832013000300016

Qin S, Hu C, Wang Y et al (2010) Tillage effects on intracellular and extracellular soil urease activities determined by an improved chloroform fumigation method. Soil Sci 175:568-572. https://doi.org/ $10.1097 / \mathrm{SS} .0 \mathrm{~b} 013 \mathrm{e} 3181 \mathrm{fa} 2810$

Qin Y, Cabral JMS (2002) Properties and applications of urease. Biocatal Biotransformation 20:1-14. https://doi.org/10.1080/ 10242420210154
Rauret G, Lopez-Sanchez JF, Sahuquillo A et al (2000) Application of a modified BCR sequential extraction (three-step) procedure for the determination of extractable trace metal contents in a sewage sludge amended soil reference material (CRM 483), complemented by a three-year stability study of acetic acid. J Environ Monit 2:228-233. https://doi.org/10.1039/b001496f

Rodak BW, de Moraes MF, Pascoalino JAL et al (2015) Methods to quantify nickel in soils and plant tissues. Rev Bras Ciência do Solo 39:788-793. https://doi.org/10.1590/01000683rbcs20140542

Ryżak M, Bartmiński P, Bieganowski A (2009) Methods for determination of particle size distribution of mineral soils. Acta Agrophysica 175:48-51

Schumacher BA (2002) Methods for the determination of total organic carbon (TOC) in soils and sediments. US. Environmental Protection Agency, Cincinnati

Sepken Kaptanoğlu Berber A, Farasat S, Namlı A (2014) Afforestation effects on biochemical soil properties. Eurasian J For Sci 2:25-34

Sumner JB (1926) The isolation and crystallization of the enzyme urease. Preliminary Paper. In: Source Book in Chemistry, 1900-1950.

Tóth G, Hermann T, Da Silva MR, Montanarella L (2016) Heavy metals in agricultural soils of the European Union with implications for food safety. Environ Int 88:299-309. https://doi.org/10.1016/j. envint.2015.12.017

Vahed HS, Shahinrokhsar P, Rezaei M (2011) Influence of some soil properties and temperature on urease activity in wetland rice soils. Am J Agric Environ Sci 11:310-313

Vodyanitskii YN (2014) Natural and technogenic compounds of heavy metals in soils. Eurasian Soil Sci 47:255-265. https://doi.org/10. 1134/S1064229314040103

Weatherburn MW (1967) Phenol-hypochlorite reaction for determination of ammonia. Anal Chem 39:971-974. https://doi.org/10.1021/ ac60252a045

Zhang C, Nie S, Liang J et al (2016) Effects of heavy metals and soil physicochemical properties on wetland soil microbial biomass and bacterial community structure. Sci Total Environ 557-558:785-790. https://doi.org/10.1016/j.scitotenv.2016.01.170

Zhang T, Wan S, Kang Y, Feng H (2014) Urease activity and its relationships to soil physiochemical properties in a highly saline-sodic soil. J Soil Sci Plant Nutr 14:304-315. https://doi.org/10.4067/s0718$95,162,014,005,000,025$

Zhao D, Li F, Wang R (2012) The effects of different urban land use patterns on soil microbial biomass nitrogen and enzyme activities in urban area of Beijing, China. Acta Ecol Sin 32:144-149. https:// doi.org/10.1016/j.chnaes.2012.04.005

Publisher's note Springer Nature remains neutral with regard to jurisdictional claims in published maps and institutional affiliations. 